\title{
Codificatie of zelfregulering in de franchisesector?
}

\author{
Mr. I.S.J. Houben, mr. J. Sterken mr.J.A.J. Devilee*
}

\section{Inleiding}

Franchising is in Nederland in opkomst geraakt na de Tweede Wereldoorlog en is sindsdien een succesvol concept voor de distributie van goederen en diensten gebleken. Sinds 1997 is het aantal franchisevestigingen zelfs verdubbeld. ${ }^{1}$ Bekende franchiseformules zijn bijvoorbeeld McDonald's, Subway, Etos, Bruna en Albert Heijn.

De afgelopen periode is er in de politiek, ${ }^{2}$ de media ${ }^{3}$ en de literatuur ${ }^{4}$ gediscussieerd over de vraag of nadere regulering van de franchiseovereenkomst noodzakelijk of op zijn minst gewenst is. Zoals bekend is de franchiseovereenkomst een onbenoemde overeenkomst, hetgeen betekent dat een wettelijke regeling van de franchiseovereenkomst ontbreekt. Er gaan inmiddels evenwel stemmen op om van de franchiseovereenkomst alsnog een benoemde overeenkomst te maken, met als overwegend doel om de franchisenemer in bescherming te nemen in zijn relatie tot de franchisegever.

Het door de jaren heen groeiend aantal franchisenemers maakt de discussie of nadere regulering gewenst of zelfs noodzakelijk is van toenemend belang. Ook de opkomst van belan-

* Mr. I.S.J. Houben is universitair hoofddocent burgerlijk recht aan de Universiteit Leiden. Mr. J. Sterk is advocaat-partner bij Ludwig \& Van Dam advocaten te Rotterdam. Mr. J.A.J. Devilee is student-stagiaire bij Ludwig \& Van Dam advocaten te Rotterdam.

1. In 1997 waren er 14.330 franchisevestigingen, in 2013 waren dit er 30.785. Dit blijkt uit onderzoek van de Nederlandse Franchise Vereniging en Panteia, mei 2014. Zie < www.nfv.nl>, Franchise Monitor 2014.

2. Rondetafelgesprek Tweede Kamer d.d. 21 mei 2014; Algemeen Overleg Tweede Kamer 12 juni 2014; Kamerstukken II 2013/14, 31311, 119 en 125-128, en Kamervragen te vinden in Aanhangsel Handelingen II 2013/14, 788, Aanhangsel Handelingen II 2013/14, 1379 en Aanhangsel Handelingen II 2013/14, 1460.

3. Tv-uitzendingen van Zembla d.d. 20 februari 2014 en EenVandaag d.d. 20 mei 2014; krantenartikelen, zie o.a. J.H. Kolenbrander, Ministers wimpelen toename van misstanden binnen franchising te gemakkelijk weg, Het Financieele Dagblad 3 januari 2014, p. 8 en J.H. Kolenbrander, Debat over franchising polariseert veel te snel, Het Financieele Dagblad 11 februari 2014, p. 10. Zie ook R. Engeman, Huidige wetgeving voldoende om mogelijke misstanden in franchise aan te pakken, Het Financieele Dagblad 15 januari 2014, p. 10. Zie ook bijv. Bakker Bart-bakkers beginnen rechtszaak tegen hoofdkantoor, De (digitale) Volkskrant 18 augustus 2014 en Drogist DA in de clinch met franchisers, Nu. nl 26 juni 2014.

4. Zie J.H. Kolenbrander, Franchising. Waarom het eigenlijk best een goed idee is om van de franchiseovereenkomst een benoemde overeenkomst te maken, NJB 2013/2302. Zie tevens J. Burgers, Reactie op artikel Kolenbrander van 8 november 2013, NJB 2014/473; Notitie Vakcentrum, Franchising en de ruimte voor zelfstandig ondernemerschap; een pleidooi voor aanpassing wetgeving, 21 januari 2014, te vinden op <www. vakcentrum.nl>. Het Vakcentrum is een brancheorganisatie voor - kort gezegd - de levensmiddelendetailhandel. genverenigingen als de recent opgerichte BVFN (Belangen Vereniging Franchisenemers Nederland) en FANed (Franchisenemers Alliantie Nederland) vormt een nadere aanwijzing dat er in de praktijk behoefte lijkt te bestaan aan belangenbehartiging voor de in sommige gevallen kwetsbare franchisenemers.

De vraag is echter of codificatie van de franchiseovereenkomst in Boek 7 van het Burgerlijk Wetboek (BW) als (enige) oplossing kan dienen. In deze bijdrage wordt bepleit dat in de discussie tot nu toe de nadruk te eenzijdig op codificatie heeft gelegen. Codificatie is een serieus te overwegen optie, zoals hierna nader uiteen wordt gezet, maar kent ook de nodige nadelen. Zelfregulering kan daarom wellicht een zinvol alternatief voor codificatie zijn, ${ }^{5}$ maar krijgt in de actuele discussie (te) weinig aandacht. Dat heeft waarschijnlijk als oorzaak dat de huidige vorm van zelfregulering, de Europese Erecode inzake Franchising (hierna: de Erecode), waarover meer in paragraaf 7, niet voldoet. Versterking van de bestaande zelfregulering is naar onze mening evenwel een serieuze optie om de gerezen problemen in de franchisesector het hoofd te bieden. Een eenzijdige focus op codificatie in de vorm van opname van de franchiseovereenkomst in Boek 7 BW bergt het risico in zich dat, vanwege de haken en ogen die aan codificatie kleven, de besluitvorming stagneert en er op korte termijn geen enkele actie wordt ondernomen.

Wij stellen in deze bijdrage daarom de vraag aan de orde of zelfregulering, naast, in plaats van of vooruitlopend op codificatie, een bijdrage kan leveren aan het oplossen van de problemen die in de franchisesector spelen (zie hierover par. 3).

Alvorens deze vraag te beantwoorden geven wij eerst een omschrijving van de franchiseovereenkomst en besteden wij aandacht aan de knelpunten die in de franchisesector zoal worden ervaren en waarvoor een oplossing wordt gezocht. Daarna wordt een rechtsvergelijking gemaakt met Spanje, Italië en België, aangezien in (onder meer) deze Europese landen franchisewetgeving is ingevoerd. Mede naar aanleiding van deze rechtsvergelijking wordt een mogelijke codificatie van de franchiseovereenkomst in Boek 7 BW besproken. Daarbij komen de argumenten voor en tegen codificatie van de franchiseovereenkomst aan de orde. Vervolgens komt de huidige vorm van zelfregulering in Nederland aan bod en wordt een

5. Of als aanvulling dienen; codificatie en zelfregulering sluiten elkaar niet uit. 


\section{Maandblad \\ Vermogensrecht}

voorschot gegeven op het versterken en uitbreiden van deze vorm van regulering. Tot slot volgt een conclusie met onze aanbevelingen.

\section{Afbakening en omschrijving franchiseovereenkomst}

Er bestaat in Nederland geen wettelijke definitie van de franchiseovereenkomst. De Erecode kent wel een definitie, evenals het Draft Common Frame of Reference (DCFR; zie hierover par. 5.2). ${ }^{6}$ In de literatuur zijn eveneens (deels uiteenlopende) omschrijvingen voorhanden. ${ }^{7}$ De Hoge Raad haakte in het arrest Paalman/Lampenier ${ }^{8}$ aan bij de volgende omschrijving van de franchiseovereenkomst uit een Europese mededingingsrechtelijke verordening: ${ }^{9}$

'Een overeenkomst krachtens welke een onderneming, de franchisegever, de wederpartij, de franchisenemer, tegen rechtstreekse of indirecte geldelijke vergoeding het recht verleent een franchiseonderneming te exploiteren voor de afzet van bepaalde typen goederen en/of de verrichting van bepaalde diensten; zij omvat ten minste verplichtingen met betrekking tot:

6. Het DCFR is een 'gemeenschappelijk referentiekader', in de vorm van artikelsgewijze behandeling van het vermogensrecht, opgesteld door academici in opdracht van de Europese Commissie. Study Group on a European Civil Code/Research Group on EC Private Law (Acquis Group) (red.), Draft Common Frame of Reference (DCFR). Full edition. Principles, definitions and model rules of European private law, München: Sellier 2009, p. 2395. Zie ook P.C.J. de Tavernier \& J.A. van der Weide, Naar een Europees Burgerlijk Wetboek? Het Draft Common Frame of Reference (DCFR), MvV 2011, afl. 5, p. 121-137.

7. Zie bijv. E.M. Kneppers-Heijnert, Een economische en juridische analyse van franchising tegen de achtergrond van een property rights- en transactiekostenbenadering (diss. Groningen), Groningen: Drukkerij van Denderen BV 1988, p. 14; A.J.J. van der Heiden, Franchising, definitie, werkwijze, in- en externe aansprakelijkheid (diss. Amsterdam UvA), Deventer: Kluwer 1999, p. 27-83, 85-88 en 179.

8. Zie HR 25 januari 2002, ECLI:NL:HR:2002:AD7329, NJ 2003/31 m.nt. J.B.M. van der Vranken, r.o. 3.2. Vranken heeft onder meer kritiek op het feit dat de Hoge Raad aansluit bij de omschrijving van franchise uit een verordening die ten eerste niet geschreven is om de verhouding tussen franchisegever en -nemer weer te geven, maar louter zag op de mededingingsaspecten, en ten tweede ten tijde van het wijzen van de uitspraak reeds was vervangen door een nieuwe verordening, waarin geen omschrijving van franchising meer voorkwam (zie noot 9). Dat heeft Rb. Overijssel 9 april 2014, ECLI:NL:RBOVE:2014:1985, r.o. 4.4 er niet van weerhouden om bij dezelfde omschrijving aan te sluiten. Overigens gebruiken niet alle (lagere) rechters deze definitie, zie ter illustratie Rb. Den Haag 19 september 2012, ECLI:NL:RBSGR:2012:BY1753, r.o. 4.1-4.2. Hoewel dit niet expliciet staat vermeld, lijkt de kwalificatie in laatstgenoemde uitspraak aan te haken bij de beschrijving neergelegd in de Erecode.

9. Verordening inzake de groepsvrijstelling voor franchiseovereenkomsten: Verordening (EEG) 4087/88 van de Commissie van 30 november 1988 inzake de toepassing van art. 85, lid 3, van het Verdrag op groepen franchiseovereenkomsten (PbEG 1988, L 359/46). In een latere Europese verordening betreffende verticale overeenkomsten wordt geen beschrijving gegeven van de 'franchiseovereenkomst', enkel van 'franchising'. Zie Verordening (EG) 2790/1999 van de Commissie van 22 december 1999 betreffende de toepassing van art. 81, lid 3, van het Verdrag op groepen verticale overeenkomsten en onderling afgestemde feitelijke gedragingen.
- het gebruik van een gemeenschappelijke naam of een gemeenschappelijk embleem en een uniforme opzet van de contractsvestiging en/of vervoermiddelen

- de mededeling door de franchisegever aan de franchisenemer van know-how, en

- de voortdurende verlening van commerciële of technische bijstand door de franchisegever aan de franchisenemer gedurende de looptijd van de overeenkomst.'

De franchiseovereenkomst vertoont verwantschap met andere typen commerciële overeenkomsten, zoals de agentuur- en de distributieovereenkomst, maar kan daarvan wel worden onderscheiden.

De distributieovereenkomst is, evenals de franchiseovereenkomst, onbenoemd. Bij de distributieovereenkomst worden door de distributeur goederen in eigen naam en voor eigen risico gekocht, die deze goederen daarna in eigen naam en voor eigen rekening aan derden verkoopt. ${ }^{10}$ De franchiseovereenkomst heeft met de distributieovereenkomst gemeen dat zij beide duurovereenkomsten zijn, ten behoeve van de afzet van producten of diensten aan derden, waarbij de distributeur of franchisenemer voor eigen rekening en risico en in eigen naam handelt. De franchiseovereenkomst onderscheidt zich met name van reguliere distributieovereenkomsten door de uniforme uitstraling van de onderneming die essentieel is voor franchise. De franchiseovereenkomst geeft daarom aan de franchisenemer het recht het businessmodel van de franchisegever te gebruiken. Dit houdt ook het gebruik in van intellectuele eigendomsrechten, waaronder de merknaam, tegen betaling van een fee door de franchisenemer. ${ }^{11}$ Alle franchisevestigingen van McDonald's hebben bijvoorbeeld hetzelfde bedrijfslogo, lijken qua inrichting op elkaar en werken met dezelfde producten.

In tegenstelling tot de franchiseovereenkomst is de agentuurovereenkomst wettelijk geregeld. ${ }^{12} \mathrm{Bij}$ de agentuurovereenkomst geldt dat de ene partij (de principaal) aan de andere partij (de handelsagent) opdraagt en deze zich verbindt voor bepaalde of onbepaalde tijd en tegen beloning te bemiddelen bij de totstandkoming van overeenkomsten. Een van de meest kenmerkende verschillen tussen de franchiseovereenkomst en de agentuurovereenkomst is dat bij agentuur het economisch risico in beginsel bij de principaal rust. Bij franchising berust het economisch risico in beginsel bij de franchisenemer. ${ }^{13}$

\section{Knelpunten franchiseovereenkomst}

Ter beantwoording van de vraag of regulering van de franchiseovereenkomst aangewezen is, en zo ja, welke regulering dan opportuun zou zijn, is van belang om eerst de bestaande knelpunten te identificeren. Deze knelpunten manifesteren zich zowel vóór het sluiten van de franchiseovereenkomst, in de

10. Zie Asser/Tjong Tjin Tai 7-IV* 2009/59.

11. HvJ EG 28 januari 1986, zaak 161/84, NJ 1988/163, Jur. 1986, p. 359 (Pronuptia), r.o. 15; Acquis Group 2009 (toelichting DCFR), p. 2383.

12. Zie art. 7:428 e.v. BW.

13. Zie over het onderscheid tussen agentuur en franchise nader Kamerstukken II 1988/89, 20842, 6; S. Claeys, Franchising, Brugge: Die Keure 2009 , p. 610 . 
precontractuele fase, als tijdens de looptijd van de overeenkomst, alsook bij en na de beëindiging van de franchiseovereenkomst. Uit onderzoek van Nederlandse jurisprudentie van de afgelopen zes jaar ${ }^{14}$ blijkt dat een aantal geschilpunten steeds terugkeert. Dit zijn bijvoorbeeld het al dan niet verstrekken van een exploitatieprognose of het verstrekken van een prognose die achteraf onvolledig, onjuist of niet realiseerbaar blijkt te zijn, zaken die betrekking hebben op de huurovereenkomst of de koppeling daarvan aan de franchiseovereenkomst en de beëindiging van de franchiseovereenkomst. Uit de rechtspraktijk blijkt voorts dat er ook op procedurele en publiekrechtelijke onderdelen complicaties bestaan, zoals ten aanzien van forum- en/of rechtskeuzes, ${ }^{15}$ concurrentiebedingen, afnameverplichtingen en het gebruik van e-commerce door franchisegever en -nemer.

Indien de uitspraken omtrent de franchiseovereenkomst van 2008 tot en met 2013 worden vergeleken, blijkt overigens dat het aantal procedures waarin een einduitspraak werd gewezen niet of nauwelijks is gestegen sinds 2008. Voorts bleek dat rechtszaken over de 'problemen' waarover wordt gesproken in de media en politiek, zoals het verstrekken van exploitatieprognoses en de beëindiging van de franchiseovereenkomst, geen (extreme) toename kennen. Het beeld dat naar voren komt uit de huidige discussie van een groeiend aantal problemen rondom de franchiseovereenkomst lijkt vooralsnog niet te hebben geleid tot een aanzienlijke toename van het aantal procedures. ${ }^{16}$ Evenwel zorgt de veranderende, meer complexe, detailhandelsstructuur ervoor dat de behoefte aan bescherming wel degelijk aanwezig en wellicht zelfs noodzakelijk is. ${ }^{17}$ Voorts wordt, zoals reeds aangegeven, het beeld bevestigd dat er een aantal terugkerende onderwerpen is waarover met enige regelmaat wordt geprocedeerd. Eerdere jurisprudentie biedt kennelijk wat betreft die onderwerpen niet voldoende houvast aan partijen om zelf tot een oplossing te geraken. De rechtspraak is dan ook niet altijd eenduidig; zij is uit de

14. Dit jurisprudentieonderzoek heeft betrekking op (eind)uitspraken betreffende de franchiseovereenkomst over de periode 2008-2013. In dit onderzoek is gebruik gemaakt van Rechtspraak.nl, waarbij 'franchiseovereenkomst' als zoekterm is ingevoerd. Onderzocht is welke partij (franchisegever of franchisenemer) door de rechter in het gelijk werd gesteld en of de uitspraak (van Kamerleden M. Li Vos en J. Recourt) 'toename van misstanden in franchiseland' wetenschappelijk kon worden gestoeld. Er geldt overigens een aantal beperkingen bij deze methode van onderzoek, zie noot 16 .

15. Zie ter illustratie Hof Amsterdam 20 augustus 2013, ECLI:NL: GHAMS:2013:2580. Vgl. art. X.33 Wetboek van Economisch Recht (België), waarin de Belgische rechter bevoegdheid krijgt toegekend indien de activiteit waarop de overeenkomst slaat hoofdzakelijk in België wordt uitgeoefend.

16. Een mogelijke verklaring daarvoor is dat procederen voor veel franchisenemers in deze jaren van economische crisis te kostbaar is geworden. Partijen kunnen ervoor kiezen om te overleggen en/of te schikken, hetgeen in de praktijk ook gebeurt. Enige voorzichtigheid is geboden bij het trekken van conclusies, onder meer vanwege het feit dat niet alle rechtspraak wordt gepubliceerd. Zie de voorgaande noot.

17. Dit komt bijvoorbeeld mede door de komst van internet. aard der zaak casuïstisch, maar bovendien komt de rechter soms in soortgelijke zaken tot een ander oordeel. ${ }^{18}$

Een van de terugkerende geschilpunten betreft het verstrekken van exploitatieprognoses aan de franchisenemer. Wij gaan op dit punt kort nader in, omdat de wens om de franchiseovereenkomst te codificeren voor een belangrijk deel wordt ingegeven door de behoefte aan bescherming die de franchisenemer juist voorafgaand aan het sluiten van de franchiseovereenkomst zou hebben. Bovendien regelt buitenlandse wetgeving inzake franchiseovereenkomsten voornamelijk dit onderdeel.

\section{Precontractuele informatieplicht}

In tegenstelling tot bijvoorbeeld België, Frankrijk en Italië kent Nederland geen specifieke wettelijke informatieplicht voor de franchisegever. ${ }^{19}$ De Hoge Raad heeft in het eerdergenoemde arrest Paalman/Lampenier geoordeeld dat er behoudens bijzondere omstandigheden geen plicht bestaat tot het verstrekken van exploitatieprognoses. ${ }^{20}$ De Erecode bevat wel een dergelijke verplichting, althans indien er financiële ramingen beschikbaar zijn, ${ }^{21}$ maar zoals hierna nog aan de orde zal komen, is deze Erecode een vorm van zelfregulering die bij lang niet alle franchiseovereenkomsten toepassing vindt.

Ondanks het feit dat er in Nederland geen specifieke wettelijke informatieplicht voor de franchisegever bestaat, zal een weldenkend franchisenemer de samenwerking in de regel pas aangaan wanneer hij een indicatie heeft van wat hij kan gaan verdienen. Derhalve wordt ook in Nederland in de praktijk meestal precontractuele informatie verstrekt, waaronder een omzet- en winstprognose. Een exploitatieprognose kan gegevens bevatten omtrent de omzet van de vorige franchisenemer (indien het geen nieuwe vestiging betreft), de gemiddelde landelijke omzet van franchisenemers en de te verwachten omzet voor de aanstaand franchisenemer.

Het enkele feit dat prognoses niet worden gehaald, betekent niet dat de franchisegever zijn informatieplicht heeft geschonden. Andere factoren, zoals een plotselinge daling van de vraag naar bepaalde producten of niet-adequate bedrijfsvoering van de franchisenemer, kunnen daarbij ook een rol spe-

18. Zie bijv. over de kwalificatie van een overeenkomst als franchiseovereenkomst Rb. Den Haag 19 september 2012, ECLI:NL:RBSGR: 2012:BY1753, r.o. 4.1-4.2 en Rb. Den Haag 9 november 2013, ECLI:NL:RBSGR:2013:15485, r.o. 3.8.

19. Hierbij zij opgemerkt dat deze informatieplicht in de genoemde landen niet het verstrekken van omzet- en winstprognoses omvat. Wel dienen bijvoorbeeld gegevens over de in het verleden behaalde resultaten, alsmede marktonderzoeken, te worden verstrekt. Zie voor België het zeer recent in werking getreden hoofdstuk X van het Wetboek van Economisch Recht (hierna: WER). In Frankrijk betreft het décret no. 91-337, 4 april 1991, betreffende de toepassing van art. 1 van loi no. 89-1008 van 31 december 1989 (nieuwe tekst van dit laatste artikel inmiddels geplaatst in art. L. 330-3 C.com).

20. HR 25 januari 2002, ECLI:NL:HR:2002:AD7329, NJ 2003/31, r.o. 3.3.3.

21. Art. 4.3 Erecode, te raadplegen via <www.nfv.nl>. 


\section{Maandblad \\ Vermogensrecht}

len. ${ }^{22}$ Wel wordt volgens de vigerende jurisprudentie de eis gesteld dat verstrekte prognoses berusten op grondig en deugdelijk onderzoek. $^{23}$

De franchisenemer kan bij schending van de informatieplicht door de franchisegever verschillende remedies uit het algemene contractenrecht trachten in te zetten, zoals een vordering tot vernietiging van de overeenkomst, dan wel nadeelcompensatie, op grond van dwaling. In dat laatste geval speelt uiteraard de eigen onderzoeksplicht van de franchisenemer een rol, een belangrijke reden waarom een dergelijke vordering lang niet altijd succesvol is. Ook wordt - eveneens met wisselend succes - getracht de overeenkomst te ontbinden of schadevergoeding te vorderen wegens een toerekenbare tekortkoming in de nakoming van een precontractuele verbintenis gebaseerd op redelijkheid en billijkheid of om schadevergoeding te vorderen op grond van een onrechtmatige daad. ${ }^{24}$

Zoals eerder aan de orde kwam, bestaat er in andere Europese rechtsstelsels wetgeving inzake franchise. Deze ziet in het bijzonder op te verschaffen informatie in de precontractuele fase van de franchiseovereenkomst. Wij zullen hierop nader ingaan.

\section{Rechtsvergelijking wetgeving}

Internationaal gezien vallen globaal drie categorieën franchisewetgeving te onderscheiden: (1) regelingen die betrekking hebben op mededinging, (2) regelingen met betrekking tot buitenlandse handel en de daarmee samenhangende investeringen en (3) regelingen in de vorm van wetgeving gebaseerd op de franchiserelatie tussen partijen onderling. Onder meer in de Verenigde Staten, Australië, Frankrijk, Spanje en België is de franchisewetgeving gebaseerd op de relatie tussen (beoogde) contractspartijen. ${ }^{25}$ De discussie die in Nederland recent is

22. Zie bijv. Rb. Den Haag 19 september 2012, ECLI:NL:RBSGR 2012:BY1753, r.o. 4.3-4.16, Rb. Gelderland 5 februari 2014 , ECLI:NL:RBGEL:2014:1562, r.o. 4.12 en Rb. Noord-Nederland 29 november 2013, ECLI:NL:RBNNE:2013:7307.

23. Zie bijv. Rb. Overijssel 9 april 2014, ECLI:NL:RBOVE:2014:1985, Prg. 2014/120 m.nt. A.J.J. van der Heiden, r.o. 4.18. Vgl. HR 19 februari 1993, Prg. 1996/4449 (Renault). Vgl. HR 25 januari 2002, ECLI:NL:HR:2002:AD7329, NJ 2003/31 en Rb. Breda (ktr.) 21 december 2011, Prg. 2012/62 m.nt. A.J.J. van der Heiden, waarin verwijzing naar overige rechtspraak.

24. Zie recent o.m. Rb. Arnhem 4 december 2012, ECLI:NL:RBARN: 2012:BY7750 (geen geslaagd beroep op dwaling, ontbinding of onrechtmatige daad wegens achterblijven ledenaantal sportschool bij prognose), Rb. Noord-Nederland 15 januari 2014, ECLI:NL:RBNNE:2014:173 (geslaagd beroep op dwaling en schadevergoeding op grond van onrechtmatige daad omdat prognose niet deugdelijk is opgesteld), Rb. Amsterdam 2 juli 2014, ECLI:NL:RBAMS:2014:3831 (franchisegever heeft aan informatieplicht voldaan) en Rb. Overijssel 9 april 2014, Prg. 2014/120 m.nt. A.J.J. van der Heiden. Zie ook J.H. Kolenbrander, De 'prognoseproblematiek' revisited: een korte bespreking van jurisprudentie aangaande de zorgplicht van de franchisegever, Contracteren 2012, p. 159-162 en E.B.M. Brons-Stikkelbroeck \& J.J.W. Kappert, Uitsluiting van dwaling in franchiseovereenkomsten, Contracteren 2010, p. 5-11, onder verwijzing naar rechtspraak.

25. Zie M. Abell, The regulation of franchising around the world, International Journal of Franchising Law 2011, p. 3-4. opgelaaid over codificatie van de franchiseovereenkomst ${ }^{26}$ heeft eveneens betrekking op wetgeving die de verhouding tussen partijen zou moeten gaan reguleren. ${ }^{27}$

Het verdient aanbeveling om voorafgaand aan een beslissing om in Nederland franchising wettelijk te reguleren rechtsvergelijkend onderzoek te doen. In een dergelijk onderzoek kan worden bekeken op welke wijze buitenlandse wettelijke regelingen vorm hebben gekregen en of deze wetgeving de positie van de franchisenemer inderdaad heeft verbeterd. ${ }^{28}$ Het voert te ver om in het bestek van deze bijdrage een dergelijk onderzoek uit te voeren, maar enige aanzetten daartoe kunnen wel worden gegeven. Wij concentreren ons op een aantal Europese landen waar betrekkelijk recent wetgeving inzake franchise is ingevoerd.

\subsection{Voorbeelden: wetgeving Spanje, Italië en België}

In verschillende Europese landen is in de afgelopen vijftien à twintig jaar wetgeving met betrekking tot de franchiseovereenkomst ingevoerd. Deze wetgeving concentreert zich op het versterken van de positie van de franchisenemer en bevat daartoe in ieder geval informatieplichten voor de franchisegever jegens de franchisenemer. ${ }^{29}$ In sommige gevallen regelt zij ook onderdelen van de verhouding tussen franchisegever en franchisenemer gedurende de looptijd van de overeenkomst. Het feit dat een aantal Europese landen het noodzakelijk heeft geacht wetgeving in te voeren teneinde de als 'zwakke' contractspartij beschouwde franchisenemer te beschermen, lijkt ons een signaal dat de verhouding tussen franchisegever en franchisenemer niet altijd evenwichtig te noemen is. Franchise is immers een internationaal vergelijkbaar concept, waarbij uiteraard wel geldt dat het algemeen civielrechtelijke instrumentarium dat aan de franchisenemer ten dienste staat per land kan verschillen. Frankrijk had als eerste land in Europa wetgeving die (mede) van toepassing is op de franchiseover-

26. De vraag naar de wenselijkheid van codificatie van de franchiseovereenkomst speelt al langere tijd. Zie Kamerstukken II 1988/89, 20842, 9 en Van der Heiden 1999, p. 363-414, waarin een voorstel tot wetgeving wordt gedaan. Wetgeving ter bescherming van de franchisenemer wordt o.a. bepleit in: O. Bueno Díaz, Franchising in European contract law (diss. Amsterdam UvA), München: Sellier 2008, p. 21 en F.W. Grosheide, Werk in uitvoering. Interview met prof. mr. M.W. Hesselink, Contracteren 2007, p. 49-50.

27. Zie Aanhangsel Handelingen II 2013/14, 788.

28. Kolenbrander (2013) stelt deze laatste vraag voor de situatie in de VS, omdat daar reeds langer specifiek op franchising gerichte wetgeving bestaat.

29. Zie voor een rechtsvergelijkend overzicht van landen in Europa met een precontractuele informatieplicht rustend op de franchisegever: M. Abell, The regulation of franchising in the European Union (diss. Londen), 2011, par. 3.5.1 en 3.5.2. 
eenkomst. ${ }^{30}$ Daarna volgden onder meer Italië, Spanje en België, waar betrekkelijk recent franchisewetgeving is ingevoerd of aangepast. Zowel het Italiaanse als het Spaanse recht kent bovendien een wettelijke definitie van franchise. ${ }^{31}$

\section{Spanje}

In Spanje geldt naast de verplichting van de franchisegever om voorafgaande aan het sluiten van de overeenkomst de franchisenemer bepaalde informatie te verschaffen, ook de verplichting voor iedere franchisegever om zich (als onderneming) te registreren in een openbaar register van franchisegevers. ${ }^{32} \mathrm{Bij}$ die registratie wordt om informatie gevraagd en er geldt een verplichting om de informatie te actualiseren. De bedoeling is dat de franchisenemer door raadpleging van het register zou kunnen beoordelen of hij in zee gaat met een bonafide franchisegever. De regels zijn inmiddels aangescherpt om de kwaliteit van de informatie in het register te waarborgen; franchisegevers moeten jaarlijks doorgeven hoeveel franchisevestigingen er zijn geopend en gesloten. Wordt de gevraagde informatie niet aangeleverd, dan kan schrapping uit het register plaatsvinden, waardoor de franchisegever zijn activiteiten moet staken. ${ }^{33}$

\section{Italie}

In het Italiaanse recht is niet alleen een definitie opgenomen van franchise, waarbij overigens wordt uitgegaan van een contract tussen twee economisch en juridisch onafhankelijke par-

30. Décret no. 91-337, 4 april 1991, betreffende de toepassing van art. 1 van loi no. 89-1008 van 31 december 1989 (nieuwe tekst van deze laatste bepaling inmiddels geplaatst in art. L. 330-3 C.com). Deze wet ziet niet louter op franchising, maar op 'toute personne qui met à la disposition d'une autre personne un nom commercial, une marque ou une enseigne, en exigeant d'elle un engagement d'exclusivité ou de quasi-exclusivité pour l'exercice de son activité'. Minimaal twintig dagen voorafgaand aan het sluiten van de overeenkomst dient een document met informatie te worden verstrekt, bijvoorbeeld over de ervaring van de onderneming (franchisegever) en de marktomstandigheden. In de Franse rechtspraak is uitgemaakt dat de wetgeving geen verplichting op de franchisegever legt om een volledige en diepgaande marktanalyse te verstrekken. Hij is evenwel wel verplicht om een betrouwbare weergave te verschaffen van de staat van de markt. Zie nader M. Hertz \& C. Mermet, France, in: D. Campbell \& A. Netzer (red.), International franchising (The Comparative Law Yearbook of International Business, Vol. 29a, 2007), Alphen aan den Rijn: Kluwer Law International 2008, p. 165-178.

31. In Italië staat deze definitie in art. 1 van een afzonderlijke wet inzake franchising ('affiliazione commerciale'), wet van 6 mei 2004, n. 129 (L nr. $129 / 2004)$. In Spanje staat de omschrijving niet in een afzonderlijke wet, maar in een afzonderlijk artikel (art. 62) over franchising ('franquicia') in de Ley de Ordenación del Comercio Minorista, Ley 7/1996 van 15 januari 1996. In België geldt een algemene beschrijving voor de commerciële samenwerkingsovereenkomst, waaronder ook franchise wordt verstaan, zie art. X.26 WER.

32. Deze verplichting staat beschreven in art. 62 lid 2 van de Ley de Ordenación del Comercio. Zie voorts Bueno Díaz 2008, p. 40-41.

33. Het niet voldoen aan de registratieplicht kan worden beboet met een boete van maximaal $€$ 30.000, art. 68.2 Ley de Ordenación del Comercio. Zie over franchise in Spanje nader V. Enrich, Spain, in: D. Campbell \& A. Netzer, International franchising (The Comparative Yearbook of International Business, Vol. 29a, 2007), Alphen aan den Rijn: Kluwer Law International 2008 en Bueno Díaz 2008, p. 19-20. tijen, ${ }^{34}$ maar zijn bijvoorbeeld ook de vorm (schriftelijk op straffe van nietigheid), een minimale looptijd van drie jaar en de inhoud van het contract gereguleerd. Tevens is bepaald dat de franchisegever, alvorens hij een franchisenetwerk mag opzetten, zijn formule commercieel beproefd dient te hebben. Ook is een precontractuele informatieplicht van de franchisegever vastgelegd. ${ }^{35}$ Deze omvat de verplichting om ten minste dertig dagen voor het ondertekenen van het contract een exemplaar daarvan aan de franchisenemer te doen toekomen, waarin onder meer moet zijn opgenomen dat bij het eerste verzoek daartoe van de franchisenemer de franchisegever zijn balans van de afgelopen drie jaar moet overhandigen, waarin een lijst is opgenomen van de reeds bestaande franchisenemers en de eigen filialen van de franchisegever, alsmede de rechtszaken of arbitragezaken waarbij de franchisegever de afgelopen drie jaar betrokken is geweest. Beide partijen kunnen het contract beëindigen indien een van de partijen onjuiste informatie heeft verschaft. ${ }^{36}$ Voorts kan schadevergoeding worden geëist. ${ }^{37}$

\section{België}

In België bestaat wetgeving inzake de zogeheten 'commerciële samenwerkingsovereenkomst'. De term franchiseovereenkomst wordt niet gebruikt, maar de omschrijving van de commerciële samenwerkingsovereenkomst makt duidelijk dat de franchiseovereenkomst binnen die omschrijving valt. Het betreft een 'overeenkomst gesloten tussen meerdere personen, waarbij de ene persoon het recht verleent aan de andere om bij de verkoop van producten of de verstrekking van diensten een commerciële formule te gebruiken onder één of meerdere van de volgende vormen: Een gemeenschappelijk uithangbord; een gemeenschappelijke handelsnaam; een overdracht van knowhow en/of commerciële of technische bijstand'. ${ }^{38}$

Recent is de afzonderlijke Wet betreffende commerciële samenwerkingsovereenkomsten uit december 2005 vervangen door een regeling van de commerciële samenwerkingsovereenkomsten in het Wetboek van Economisch Recht (hierna: WER). Het betreft art. $26 \mathrm{t} / \mathrm{m} 34$ van Boek X WER. ${ }^{39}$ Op grond van art. X.27 WER dient de franchisegever op straffe van nietigheid één maand voor het sluiten van de commerciële samenwerkingsovereenkomst een ontwerp van overeenkomst en een afzonderlijk document te verstrekken aan de franchisenemer. Zowel onder het oude als onder het nieuwe recht ${ }^{40}$

34. Art. 1 L nr. 129/2004: 'L'affiliazione commerciale (franchising) è il contratto, comunque denominato, fra due soggetti giuridici, economicamente e giuridicamente indipendenti (...).'

35. Art. 4 en 6, L nr. 129/2004.

36. Art. 8 onder verwijzing naar art. 1439 CC (dolo), vergelijkbaar met onze regeling van bedrog; respectievelijk art. 3 .

37. Art. 8, L nr. 129/2004. Overigens zien deze sancties op het verschaffen van onjuiste informatie; er is geen expliciete bepaling met betrekking tot onvolledige gegevens.

38. art. I.11 lid 2 WER.

39. Voor de (algemene) definitiebepaling (betreffende commerciële samenwerkingsovereenkomsten) verwijzen wij kortheidshalve naar art. X.26 WER.

40. Zie art. 3 Wet van 19 december 2005 betreffende de precontractuele informatie bij commerciële samenwerkingsovereenkomsten (oud); zie art. X.27 WER (nieuw). 


\section{Maandblad \\ Vermogensrecht}

dient de franchisegever minimaal één maand voor het sluiten van de franchiseovereenkomst een tweeledig document ter beschikking te stellen aan de franchisenemer dat de franchisenemer in staat stelt de overeenkomst te beoordelen. Dit document dient het ontwerp van de overeenkomst te bevatten en in een afzonderlijk bijgevoegd document dienen de belangrijkste contractuele bepalingen te zijn opgenomen alsmede gegevens voor de correcte beoordeling van de commerciële samenwerkingsovereenkomst. Deze gegevens betreffen de historiek, de staat en de vooruitzichten van het netwerk en de activiteiten vanuit algemeen en lokaal oogpunt. ${ }^{41}$ Hoewel de franchisegever deze gegevens dient te verstrekken, ontbreekt een expliciete bepaling omtrent het verstrekken van onder andere reële kosten, marges en concrete resultaten. ${ }^{42}$ Hoewel het Belgische recht in tegenstelling tot het Nederlandse recht een verstrekkingsplicht van precontractuele informatie kent, bestaat er in België geen plicht tot het verstrekken van gegevens betreffende de exploitatie van de franchiseonderneming zelf.

Onder het oude recht kon ter sanctionering de (partiële) nietigheid van de franchiseovereenkomst gedurende twee jaar worden ingeroepen bij het niet verschaffen of het ten dele (onvolledig) verschaffen van precontractuele informatie. Kritiek werd voornamelijk geleverd op het ontbreken van een sanctie ten opzichte van het verstrekken van onjuiste informatie. Het nieuwe recht bevat wel een expliciete bepaling omtrent de sanctie bij het verstrekken van onjuiste informatie. ${ }^{43}$ Evenwel is het gevolg hetzelfde gebleven als onder het oude recht. Er dient namelijk te worden teruggegrepen naar aansprakelijkheid onder het algemene recht of, in het geval van het nieuwe recht, naar quasidelictuele aansprakelijkheid. Dit betekent dat het oude Belgische recht en het nieuwe Belgische recht, maar ook het Belgische en het Nederlandse recht elkaar op dit punt niet zoveel ontlopen.

\subsection{DCFR als inspiratiebron}

Bij een eventuele codificatie van de franchiseovereenkomst zou zeker ook inspiratie kunnen worden geput uit het DCFR, ${ }^{44}$ waarin een regeling van de franchiseovereenkomst is opgenomen. ${ }^{45}$ Het DCFR is weliswaar 'slechts' soft law, maar door het internationale karakter, het uitgebreide rechtsvergelijkende materiaal en de gedetailleerdheid van de 'regelgeving' in de vorm van artikelen biedt het waardevolle informatie over mogelijke oplossingen van vraagstukken die spelen bij een franchiseovereenkomst. Bij het opstellen van het DCFR is ervoor gekozen om commerciële contracten (de agentuurovereenkomst, de franchiseovereenkomst en de distributieovereenkomst) van een gezamenlijke, algemene, regeling te voorzien, met daaropvolgend voor elk van de overeenkomsten afzonderlijke regels in een apart hoofdstuk. ${ }^{46}$ De algemene bepalingen,

41. Art. X.27 jo. art. X.28 WER.

42. Zie A. de Boeck \& B. Simpelaere, De aan de franchisenemer te overhandigen previsionele financiële plannen, 2014, p. 2 (nog niet gepubliceerd).

43. Art. X.30 WER.

44. Acquis Group 2009.

45. Art. IV.E-4:101 e.v. DCFR

46. De regeling is opgenomen in Book IV 'Specific contracts', in Part E, genaamd: Commercial agency, franchise and distributorship. die dus voor alle drie de typen overeenkomsten gelden, behelzen bijvoorbeeld een algemeen gestelde informatieplicht en een regeling van de opzegging van de overeenkomst. ${ }^{47}$ Vervolgens worden voor elk type overeenkomst afzonderlijk nadere regels gegeven. De regeling van de franchiseovereenkomst begint met een omschrijving van de overeenkomst. ${ }^{48}$ Vervolgens worden verplichtingen van de franchisegever en franchisenemer uitgewerkt, waaronder de precontractuele informatieplicht die op de franchisegever rust. Deze informatieplicht is, naar het voorbeeld van bestaande wetgeving in verschillende Europese landen, uitgewerkt in een lijst met onderwerpen waarover informatie dient te worden verschaft, zoals de omvang van het franchisenetwerk, de ervaring van de franchisegever en de contractsvoorwaarden. Daarnaast bevat de regeling in het DCFR de verplichting van de franchisegever om aan de franchisenemer toestemming te verlenen om gebruik te maken van diens intellectuele eigendomsrechten, zoals een merknaam of een logo, om knowhow over te dragen en om bijstand te verlenen gedurende de looptijd van de overeenkomst. Voorts is er een regeling opgenomen over de levering van de goederen en over de verplichting om de uniformiteit van de franchiseorganisatie te bewaren en reclame te maken. Vervolgens wordt een aantal verplichtingen die op de franchisenemer rusten geregeld, waarvan de belangrijkste is het betalen voor het gebruik van de franchiseformule (inclusief het gebruik van de intellectuele eigendomsrechten). De franchisenemer dient zijn onderneming te drijven conform het 'format' van de franchisegever en dient ook inspecties door de franchisegever toe te laten.

Aantrekkelijk aan het voorbeeld van het DCFR is naar ons idee dat de franchiseovereenkomst niet als geïsoleerde overeenkomst wordt beschouwd, maar in samenhang met andere 'verticale' overeenkomsten is geregeld. Door bepaalde aspecten, zoals de opzegging van deze (duur)overeenkomsten, gezamenlijk te regelen en de daarmee verband houdende gelaagde structuur ontstaat een normenstelsel dat uitgebreider is, meer samenhang vertoont en meer flexibiliteit kent dan wanneer louter de franchiseovereenkomst van een regeling zou zijn voorzien. ${ }^{49}$

\subsection{Tussenconclusie rechtsvergelijking}

Uit deze korte tour d'horizon van wetgeving inzake franchiseovereenkomsten in verschillende Europese landen kunnen geen al te vergaande conclusies worden getrokken, maar enige observaties zijn wel te maken. In de beschreven landen blijkt

47. Zie de general provisions in art. IV.E-2:101 t/m 2:402. Strikt genomen gelden de algemene bepalingen nog voor een ruimere categorie, namelijk 'with appropriate adaptations to other contracts under which a party engaged in business independently is to use skills and efforts to bring another party's products on to the market'.

48. Zie voor de definitie van de franchiseovereenkomst art. IV.E.-4:101 DCFR.

49. Vgl. R.L.M.M. Tan, Beëindiging van duurovereenkomsten volgens het Draft Common Frame of Reference, NTBR 2011/46. 
de wettelijke informatieplicht de grote gemene deler. ${ }^{50}$ Tevens is een omschrijving van de franchiseovereenkomst, althans een type overeenkomst dat mede de franchiseovereenkomst omvat, in de wetgeving opgenomen. De mate van gedetailleerdheid van regelgeving ten aanzien van andere aspecten van de verhouding tussen franchisegever en franchisenemer verschilt. In de drie onderzochte landen is niet gekozen voor codificatie in het Burgerlijk Wetboek, het gaat om wettelijke regelingen of om artikelen in het kader van ruimere economische of handelswetgeving. Daarbij geldt in Spanje een registratieplicht voor franchisegevers. Een en ander illustreert dat er verschillende wijzen van wettelijke regulering van de franchiseovereenkomst mogelijk zijn. De wens om de franchiseovereenkomst ook in Nederland wettelijk te regelen, betekent dus niet per definitie codificatie in Boek 7 BW, hoewel dit vooralsnog als enige optie van codificatie naar voren lijkt te worden gebracht. ${ }^{51}$ In de volgende paragraaf gaan wij nader in op de argumenten voor en tegen codificatie van de franchiseovereenkomst.

\section{Codificatie franchiseovereenkomst}

\subsection{Argumenten voor en tegen codificatie}

Om codificatie van de franchiseovereenkomst te legitimeren wordt een aantal argumenten aangevoerd. ${ }^{52}$ Als eerste argument wordt de populariteit van het fenomeen franchising aangedragen. Deze stijgende populariteit is ook daadwerkelijk aangetoond. ${ }^{53}$ Franchiseovereenkomsten vertegenwoordigen inmiddels een groot economisch belang. Het succes van franchising als distributieconcept heeft ertoe geleid dat de juridische contouren van de franchiseovereenkomst zich hebben ontwikkeld in de praktijk, zodat zij in wetgeving kan worden gedefinieerd. Dit blijkt ook uit de voorbeelden uit het buitenland. Hierbij dient wel te worden aangetekend dat het niet de bedoeling is dat elk type contract dat zich in de praktijk ontwikkelt, afzonderlijk wordt gecodificeerd. Dit zou tot versnippering leiden en ook geen recht doen aan het instrumentarium dat het algemeen vermogensrecht biedt. ${ }^{54}$ Er zijn dus meer argumenten nodig om codificatie te rechtvaardigen dan het enkele feit dat een bepaald type overeenkomst veel voorkomt.

In het geval van franchising is een nader argument dat codificatie duidelijkheid zou kunnen scheppen ten aanzien van een aantal steeds terugkerende geschilpunten. Het belang-

50. Dit geldt naast de door ons genoemde Europese landen in ieder geval ook voor Zweden en Roemenië.

51. Zie Aanhangsel Handelingen II 2013/14, 788.

52. Zie bijv. Kolenbrander 2013.

53. Zie het rapport van ING, Franchise is crisisbestendig, uit 2012.

54. Vgl. W.C.L. van der Grinten, Boek 7 BW, in: In het nu, wat worden zal (Schoordijk-bundel), Deventer: Kluwer 1991, p. 88-89 en W. Snijders, Privaatrechtelijke problemen, in: W.F. de Gaay Fortman e.a. (red.), Problemen van wetgeving, Deventer: Kluwer 1982, p. 148-185. Vlg. ook S.C.J.J. Kortmann, De overeenkomst van opdracht, de lastgeving en de geneeskundige behandelingsovereenkomst, WPNR (1990) 5982, p. 743. Zie in meer algemene zin ook aanwijzing 6.1 van de Aanwijzingen voor de regelgeving, te raadplegen via < www.overheid.nl > : Tot het tot stand brengen van nieuwe regelingen wordt alleen besloten, indien de noodzaak daarvan is komen vast te staan.' rijkste argument, dat ook in de discussie de boventoon voert, is evenwel de gestelde ongelijkwaardigheid van contractspartijen. ${ }^{55}$

Een dergelijke ongelijkwaardigheid, en daarmee de behoefte aan bescherming van de zwakke contractspartij (zoals huurders, werknemers en consumenten), is van oudsher een van de belangrijkste motieven om overeenkomsten van een bijzondere regeling in het BW te voorzien. ${ }^{56} \mathrm{Bij}$ bijzondere overeenkomsten die in Boek 7 BW zijn opgenomen vanwege beschermingsdoeleinden gaat het in de regel om dwingend recht, zodat de gewenste bescherming niet contractueel kan worden uitgesloten. Een regeling van dwingend recht levert een beperking van de contractsvrijheid op en vormt daarom een uitzondering in het contractenrecht. Wetgeving, zeker dwingende wetgeving, leidt bovendien tot fixatie en kan de verdere ontwikkeling van een contract belemmeren. Deze nadelen van het invoeren van dwingend contractenrecht worden op de koop toe genomen, indien de behoefte aan bescherming overheerst.

Uit de huidige discussie in en over de franchisesector, ${ }^{57}$ maar ook uit de jurisprudentie, blijkt evenwel dat er geen overeenstemming bestaat over de vraag óf de franchisenemer een contractspartij is die dergelijke bescherming behoeft. Volgens de Erecode is zowel de franchisegever als de franchisenemer juridisch en financieel een zelfstandige en onafhankelijke ondernemer. Ook de Hoge Raad ging daar in het arrest Paalman/Lampenier van uit. ${ }^{58}$ In lagere rechtspraak wordt deze visie niet altijd gedeeld; er zijn vele voorbeelden van uitspraken waarin de rechter aangeeft dat de franchisenemer zich in een zwakkere positie bevindt dan de franchisegever.

Deze uiteenlopende visies wat betreft de vraag of de franchisenemer een 'zwakke' contractspartij is die wettelijke bescherming behoeft, maakt dat er bij een eventuele codificatie geen sprake zou zijn van het louter in wetgeving incorporeren van een uitgekristalliseerd type overeenkomst. Er bestaat immers geen overeenstemming over de cruciale vraag of het 'normaaltype' van de franchiseovereenkomst een zakelijke overeenkomst tussen twee (min of meer) gelijkwaardige professionele partijen is, of dat moet worden uitgegaan van een normaaltype waarbij de franchisegever de sterkere partij en de franchisenemer de zwakkere partij is. De hoedanigheid van de franchisenemer varieert van onervaren zzp'er tot grote 'repeat player'. Ook de franchisegevers zijn lang niet allemaal even ervaren. Een dergelijke diversiteit is in het contractenrecht op zichzelf heel normaal en kan bijvoorbeeld worden opgelost door te differentiëren in regels al naar gelang de hoedanigheid van de contractspartij. Een duidelijk voorbeeld hiervan is de

55. Zie de hiervoor gememoreerde actuele discussie en al eerder Bueno Díaz 2008, p. 21, Grosheide 2007, p. 49-50 en Van der Heiden 1999, p. 363-414. Overigens deelt niet iedereen de analyse, zoals die ook in het DCFR naar voren komt, dat de franchisenemer veelal als zwakkere partij kan worden beschouwd. Zie bijv. (eerder) E.M. Kneppers-Heijnert, Boekbespreking, Ondernemingsrecht 2000, afl. 1, p. 26 e.v.

56. Andere motieven zijn: de behoefte aan regelend recht voor veelvoorkomende overeenkomsten als koop en een eventuele internationale verplichting om een wettelijke regeling te treffen, zoals bij de agentuurovereenkomst aan de orde was, Richtlijn 86/653 EEG.

57. Zie noot 3,4 en 5 .

58. HR 25 januari 2002, ECLI:NL:HR:2002:AD7329, NJ 2003/31. 


\section{Maandblad \\ Vermogensrecht}

regeling van de koopovereenkomst, die van regelend recht is, maar specifieke dwingendrechtelijke bepalingen kent ter bescherming van de consumentkoper. Een dergelijke differentiatie is evenwel alleen mogelijk indien de beschermenswaardige 'subgroep' gedefinieerd kan worden, en dat is nog niet zo eenvoudig binnen de groep franchisenemers (of franchisegevers).

Codificatie van de franchiseovereenkomst is dus geen 'neutrale' operatie, maar impliceert dat de wetgever de discussie over de aard van de franchiseovereenkomst beslecht ten faveure van de bescherming van de franchisenemer, zoals dat ook in enkele andere Europese landen met franchisewetgeving is gebeurd. Indien tot codificatie wordt besloten, is een belangrijke vervolgvraag hoe een dergelijke regeling eruit zou moeten zien. In de volgende paragraaf gaan wij op enkele van de vragen die daarbij rijzen nader in.

\subsection{Samenhang met andere overeenkomsten}

$\mathrm{Bij}$ een eventuele keuze om de franchiseovereenkomst te codificeren is van belang om de franchiseovereenkomst niet louter geïsoleerd te beschouwen, maar rekening te houden met verwante rechtsfiguren, zoals de distributieovereenkomst en de agentuurovereenkomst. In het mededingingsrecht worden zij aangeduid als 'verticale overeenkomsten', vanwege de weg die het product of de dienst aflegt van producent naar eindgebruiker, die men als een verticale distributiekolom kenschetst. In mededingingsrechtelijk opzicht worden deze overeenkomsten als een groep behandeld, waarbij vervolgens wel onderscheid wordt gemaakt tussen bijvoorbeeld de distributieovereenkomst en de franchiseovereenkomst. ${ }^{59}$ Het zou geen vreemde gedachte zijn om te bezien of ook in privaatrechtelijk opzicht deze overeenkomsten als een cluster kunnen worden beschouwd en gecodificeerd. ${ }^{60}$ Dit zou ervoor pleiten om een wettelijke regeling van de franchiseovereenkomst te laten aansluiten bij de reeds gecodificeerde agentuurovereenkomst en daarbij dan ook de distributieovereenkomst te betrekken. ${ }^{61}$ Daarbij verdient evenwel aantekening dat de agentuurovereenkomst geregeld is in titel 7.7 BW, als onderdeel van de overeenkomst van opdracht. De distributieovereenkomst en de franchiseovereenkomst worden over het algemeen echter niet als overeenkomst van opdracht beschouwd, onder meer omdat distributeur en franchisenemer voor eigen rekening en

59. Bepaalde verplichtingen die voortvloeien uit een franchiseovereenkomst maken geen inbreuk op het kartelverbod van art. $101 \mathrm{VWEU}$, omdat de franchiseovereenkomst ondernemers die niet de noodzakelijke kennis hebben om zelf een onderneming te starten, de mogelijkheid geeft om dat te doen door te profiteren van de knowhow van de franchisegever $(\mathrm{HvJ}$ EG 28 januari 1986, zaak 161/84, NJ 1988/163, Jur. 1986, p. 359 (Pronuptia). Franchiseovereenkomsten worden door het hof niet op zichzelf als mededingingsbeperkend beschouwd. zie nader J. Goyder, EU distribution law, Oxford/Portland, OR: Hart Publishing 2011, p. 182-190.

60. Vgl. het DCFR, waar deze drie overeenkomsten samen zijn geregeld.

61. Zelfs zou nog kunnen worden gedacht aan (een lobby voor) de invoering van EU-regelgeving, bijvoorbeeld in ansluiting op de bestaande agentuurrichtlijn. Zie het pleidooi hiervoor door Abell (diss.) 2011. risico optreden. ${ }^{62}$ Het van een samenhangende regeling voorzien van deze overeenkomsten heeft derhalve meer voeten in de aarde dan het aanvullen van de huidige regeling van agentuur met een of twee afdelingen in titel 7.7 BW.

Een belangrijke vervolgvraag met betrekking tot de eventuele codificatie van de franchiseovereenkomst is in hoeverre de gesignaleerde knelpunten uniek zijn voor de franchiseovereenkomst. Te denken valt bijvoorbeeld aan de opzegging van de franchiseovereenkomst, waarvoor in beginsel de casuïstische jurisprudentie geldt die bestaat voor opzegging van duurovereenkomsten in het algemeen. ${ }^{63}$ De problemen die daarbij rijzen, kunnen wellicht beter worden opgelost door een wettelijke regeling van de opzegging van duurovereenkomsten, waarvoor overigens ook al geruime tijd wordt gepleit, dan door een specifieke regeling van de franchiseovereenkomst.

Het meest pregnant naar voren komende juridische probleem lijkt op dit moment evenwel te zijn dat franchisenemers over onvoldoende kennis, ervaring en informatie beschikken om een goede inschatting te kunnen maken van de levensvatbaarheid van hun onderneming binnen het franchiseconcept. Het gaat dan, juridisch gezien, om de vraag in hoeverre op een contractspartij (pre)contractuele informatieplichten rusten. Dit speelt weliswaar ook een rol bij andere overeenkomsten, ${ }^{64}$ maar bij franchiseovereenkomsten speelt het informatietekort wel een bijzonder pregnante rol vanwege de investeringsbeslissing die de franchisenemer moet nemen, waarbij hij ten dele afhankelijk is van informatie waarover alleen de franchisegever beschikt. ${ }^{65}$ Andere Europese wetgevers hebben dan ook vooral dit punt gereguleerd.

\subsection{Tussenconclusie codificatie}

In deze paragraaf zijn argumenten voor en tegen codificatie van de franchiseovereenkomst aan bod gekomen. Het belangrijkste argument voor codificatie is de behoefte aan bescherming van de franchisenemer. Er bestaat evenwel discussie over de vraag of de franchisenemer wel als 'zwakke' contractspartij beschouwd moet worden. Volgens ons bestaat er wel degelijk behoefte aan bescherming van de franchisenemer. Indien wordt gekozen voor het invoeren van wettelijke bepalingen ter bescherming van de franchisenemer, dan zijn er, zoals uit de beknopte rechtsvergelijking in paragraaf 5 bleek, verschillende vormen van wetgeving denkbaar. Onze voorkeur zou uitgaan naar een gezamenlijke regeling van agentuur, distributie en

62. Over de distributieovereenkomst: Asser/Tjong Tin Tai 7-IV* 2014/59; C.A.M. van de Paverd, De opzegging van distributieovereenkomsten (diss. Amsterdam UvA), 1999, p. 32-33. Het is overigens strikt genomen wel mogelijk om de distributieovereenkomst of de franchiseovereenkomst onder de omschrijving van art. 7:400 BW te brengen, omdat daarin niets anders staat dan dat de opdrachtnemer bepaalde werkzaamheden moet verrichten buiten dienstverband.

63. Zie ter illustratie Rb. Oost-Brabant 23 april 2014, ECLI:NL:RBOBR: 2014:2305, r.o. 5.3.3.

64. Zie bijv. de recent ingevoerde art. 6:2301 en 6:230m BW, die informatieplichten behelzen bij overeenkomsten tussen handelaren en consumenten.

65. Vgl. H. Vrolijk, Efficiënte contracten? Institutioneel-economische beschouwingen over franchising (diss. Nijmegen), 2002, p. 229. 
franchise, maar zoals hiervoor aangegeven, kan daartoe niet worden volstaan met aanvulling van de regeling van agentuur in titel $7.7 \mathrm{BW}$.

Hiervoor is de optie om de franchiseovereenkomst te codificeren besproken. De behoefte aan codificatie kan afnemen indien er een effectieve vorm van zelfregulering bestaat. Bij de franchiseovereenkomst is evenwel gebleken dat de huidige vorm van zelfregulering niet voldoet. Wij gaan hier in de volgende paragraaf nader op in.

\section{Zelfregulering nu en (mogelijk) straks}

\subsection{Huidige zelfregulering}

In 1972 is de Erecode opgesteld door de Europese Franchise Federatie. ${ }^{66}$ De achterliggende gedachte van de Erecode was het opstellen van een algemeen (compromis)kader met normen voor contractspartijen, waaraan vervolgens door de franchiseverenigingen van de aangesloten landen een nationale interpretatie en aanpassing werd toegevoegd. ${ }^{67}$ De landen waar de Erecode wordt gebruikt, hebben dus elk een eigen versie van de Erecode. ${ }^{68}$ In beginsel is de Erecode uitgevaardigd met als doel een zelfregulerende set van ethische normen te bieden ter bescherming van het bedrijfsleven. ${ }^{69}$ De Erecode is geen wet, maar geeft een gedragscode weer voor betrokken contractspartijen. In beginsel verbinden enkel franchisegevers zich aan de Erecode, maar zij ziet tevens op de verhouding tussen franchisegever en -nemer. De rechter zou bij zijn oordeelsvorming rekening kunnen houden met de inhoud van de Erecode, ${ }^{70}$ bijvoorbeeld door de Erecode als commercieel gebruik of gewoonte aan te merken in het kader van uitleg of aanvulling van de overeenkomst (art. 6:248 lid 1 BW). ${ }^{71}$

Uit de praktijk blijkt evenwel dat de Erecode niet als volwaardig zelfregulerend instrument wordt gezien. Ten eerste is de Erecode niet van toepassing op alle franchisegevers, maar alleen op leden van de Nederlandse Franchise Vereniging ${ }^{72}$ (NFV). Een van de belangrijke criteria om zelfregulering als alternatief voor overheidsregulering te kunnen beschouwen,

66. De tekst van de Europese Erecode is voor het laatst gewijzigd in 2003. Zie $<$ eff-franchise.com>.

67. Zie J. Janssen, Zelfregulering franchisepraktijk, juli 2014 via Franchise.nl.

68. Zie bijv. de Duitse Ethikkodex des Deutschen Franchise-Verbandes, de Franse Code de déontologie européen de la franchise (inclusief annexes) en de Belgische Europese deontologische erecode inzake franchising (inclusief bijlagen). In Nederland is de Europese Erecode in de tekst zelf aangevuld, met name het gedeelte over de precontractuele informatieplicht.

69. Zie <eff-franchise. com>; vgl. J. Burgers, De Europese Erecode inzake Franchising, Franchiseplus 2009/6.

70. Zie <www.nfv.nl/erecode/>.

71. Vgl. P. Jeanmart, The European Code of Ethics for Franchising: Its role as a source of reference - legal and ethical - for franchising in Europe, in: R. Schulze (red.), Franchising im Europäischen Privatrecht, BadenBaden: Nomos 2001, p. 277-281.

72. De NFV is een overkoepelende belangenorganisatie voor franchisegevers. Momenteel lijkt onduidelijk hoeveel procent van de franchisegevers is aangesloten bij de NFV. Vgl. Aanhangsel Handelingen II 2013/14, 1379, waarin wordt gesproken over $30 \%$, en J. Janssen, Zelfregulering franchisepraktijk, juli 2014 ( Franchise.nl), waar wordt gesproken over 17\% aangesloten (franchise)formules. vormt de representativiteit van de regulering en daarmee het draagvlak..$^{73} \mathrm{Op}$ dit moment ontbreekt het daaraan in de franchisesector, ${ }^{74}$ maar er worden wel initiatieven ondernomen om dit te verbeteren. Een van de problemen die bij zelfregulering in handelsbranches als die van franchise speelt, ook in het buitenland, is dat organisaties die actief zijn vooral fungeren als belangenbehartiger. Er is dus over het algemeen geen neutrale organisatie die het beter functioneren van de sector als geheel als primair doel heeft. ${ }^{75}$

Ten tweede wordt zowel de inhoud als de toepasselijkheid van de Erecode op diverse manieren door rechters geïnterpreteerd. Zo oordeelde de Rechtbank Noord-Nederland onlangs dat de Erecode geen in rechte afdwingbare verplichtingen kent en hooguit de status van fatsoensnorm heeft. ${ }^{76}$ In een andere recente procedure werd voorbijgegaan aan het feit dat de franchisegever is aangesloten bij de NFV en zodoende de verplichtingen uit de Erecode zou moeten naleven. ${ }^{77}$ Het ontbreekt ook aan enig handhavingsinstrument in de Erecode zelf. Er zijn geen voorbeelden bekend waarbij franchisegevers door de eigen branche worden aangesproken op niet-naleving van de Erecode.

Al hieruit blijkt dat de Erecode als zelfreguleringsinstrument niet geheel voldoet. Daar komt bij dat de Erecode geen regels bevat omtrent laagdrempelige geschilbeslechting of uitsluiting van kostbare buitenlandse rechtsgangen en arbitrages. $^{78}$

Dit neemt niet weg dat er voordelen verbonden zijn aan zelfregulering ten opzichte van wetgeving. ${ }^{79} \mathrm{De}$ (franchise)sector heeft praktijkkennis en weet waar de knelpunten daadwerkelijk zitten. Voorts kan zelfregulering op korte termijn tot stand komen, hetgeen van belang is nu de ministers van Economische Zaken en Veiligheid en Justitie onlangs hebben laten weten dat het codificeren van de franchiseovereenkomst geen prioriteit heeft. ${ }^{80}$ Daarnaast zijn wijzigingen in het geval van 'soft law' tussentijds flexibeler in te passen dan in het geval van wetgeving. Bovendien is (over het algemeen) het draagvlak onder betrokken partijen groter, omdat de normering op een andere manier - vanuit de eigen sector - tot stand is gekomen.

73. Zie over de vereisten voor het inzetten van zelfregulering, in het bijzonder gedragscodes, bijv. het recente preadvies voor de Nederlandse Vereniging voor Burgerlijk Recht 2013: M. Menting \& J. Vranken, Gedragscodes in een meergelaagd privaatrecht in Europa en Nederland. Representativiteit, kenbaarheid en afdwingbaarheid zijn onder meer criteria die zowel in Europa als in Nederland gelden, p. 40.

74. Dit is overigens zeker geen uniek Nederlands probleem; slechts $16 \%$ van de franchisegevers in Europa is via de nationale franchiseorganisatie verbonden aan de Europese Franchise Federatie (EFF) en daarmee aan de Erecode, aldus Abell (diss.) 2011, p. 119.

75. Vgl. Abell (diss.) 2011, p. 116-118 voor de situatie in Groot-Brittannië.

76. Zie Rb. Noord-Nederland 29 november 2013, ECLI:NL:RBNNE: 2013:7307, r.o. 5.15.

77. Rb. Limburg 26 februari 2014, ECLI:NL:RBLIM:2014:2557.

78. Zie Hof Amsterdam 3 juni 2014, ECLI:NL:GHAMS:2014:2270, r.o. 2.1-2.4.

79. Zie in dit kader H.L. de Boer \& R.M.L.A. Martius, Zelfregulering: een goed en betrouwbaar alternatief voor publieke regulering, TFR 2014, afl. 6, p. 232-235.

80. Zie Aanhangsel Handelingen II 2013/14, 788. Zie tevens de kabinetsreactie op meerdere stukken op het gebied van franchiseondernemers d.d. 14 mei 2014. 


\subsection{Mogelijkheden tot versterking van zelfregulering}

\section{Inrichten van overleg}

De branche zou op de bestaande behoefte aan regulering kunnen inspelen door middel van het organiseren van overleg tussen franchisegevers en franchisenemers. Indien zelfregulering wil slagen, dient te worden voorkomen dat er 'versplinterde' initiatieven volgen. Het is van belang voldoende draagvlak binnen de sector te creëren. Tot op heden zijn er blijkbaar onvoldoende prikkels geweest voor franchisegevers en franchisenemers om zich aan te sluiten bij een overkoepelende vereniging. De NFV staat alleen open voor franchisegevers. Voor franchisenemers bestonden tot kort geleden geen brancheoverstijgende organisaties. ${ }^{81}$ De recente oprichting van twee belangenverenigingen voor franchisenemers, ${ }^{82}$ laat zien dat de franchisesector wat dit betreft in beweging is. Naar ons idee zou de roep om wettelijke verankering van de franchiseovereenkomst voor franchisegevers een prikkel kunnen vormen om zelfregulering serieus ter hand te nemen.

Verschillende modellen zijn denkbaar voor een dergelijk overleg, zoals het instellen van een overkoepelend overlegorgaan met vertegenwoordigers van franchisegevers en franchisenemers, of het opnemen van franchisegevers en franchisenemers in één organisatie, naar Frans voorbeeld (waar als enige in Europa een franchiseorganisatie bestaat waarin zowel franchisegevers als franchisenemers actief participeren ${ }^{83}$ ). Wij denken hierbij bijvoorbeeld aan een overleg zoals dat op verschillende terreinen binnen het kader van de SER plaatsvindt. ${ }^{84}$

\section{Inhoud van het overleg: modelcontracten}

Binnen het kader van een dergelijk overlegorgaan zouden nieuwe typen modelcontracten kunnen worden opgesteld. Hierbij kan worden ingesprongen op de behoefte aan duidelijkheid omtrent bijvoorbeeld informatieplichten, termijnen bij beëindiging van de franchiseovereenkomst, e-commerce en concurrentiebedingen. Voorts bestaat de optie om de huidige Erecode als uitgangspunt te nemen en deze te concretiseren en uit te breiden, bijvoorbeeld met een bepaling over forum-/ rechtskeuzes.

Naast overleg over de inhoud van de overeenkomst, zou ook overleg plaats kunnen vinden over verbetering van de informatievoorziening in de precontractuele fase. Dit betreft het geven van voorlichting aan aspirant-franchisenemers over bijvoorbeeld malafide franchisegevers, veelvoorkomende con-

81. Binnen sommige formules bestaan wel franchisenemersverenigingen. Zie over de belemmeringen die er (in de VS) voor dergelijke verenigingen die binnen een formule opereren kunnen bestaan om voldoende leden te krijgen en een volwaardige onderhandelingspartner voor de franchisegever te worden: R.W. Emerson \& U. Benoliel, Can franchisee organisations serve as a substitute for franchisee protection laws?, Penn State Law Review 2013, p. 99-128.

82. Belangen Vereniging Franchisenemers Nederland (BVFN) en FANed (Franchisenemers Alliantie Nederland).

83. Féderation Française de la Franchise, zie $<$ franchise-fff.com $>$. Zie tevens in dit kader Abell (diss.) 2011, p. 118.

84. Zie eerdergenoemd preadvies over Gedragscodes (noot 73), waarin als geschikt procedureel kader voor het opstellen van gedragscodes wordt gewezen op overleg onder leiding van de SER, p. 41. tractuele valkuilen in franchiseovereenkomsten en ondernemersrisico's. Voor franchisegevers geldt overigens ook dat zij behoefte kunnen hebben aan voorlichting en begeleiding bij de selectie van capabele franchisenemers. Een organisatie waarin franchisegevers en franchisenemers vertegenwoordigd zijn, zou hier goede diensten kunnen bewijzen. Te denken valt aan het organiseren van informatie-uitwisseling tussen leden van een dergelijke organisatie, bijvoorbeeld door het ontwikkelen van studie- en voorlichtingsdagen, het onderhouden van een website en het organiseren van voorlichtingsbijeenkomsten voor aspirant-franchisegevers en -nemers. ${ }^{85}$

\section{Geschilbeslechting}

Geschilbeslechting is een belangrijk aspect van succesvolle zelfregulering. De NFV biedt mediation en arbitrage aan. ${ }^{86}$ Dit zijn naar onze mening belangrijke instrumenten, omdat partijen die met elkaar verder willen tijdens mediation en arbitrage minder van elkaar vervreemd raken dan in een jarenlange en kostbare gang naar de rechter. ${ }^{87}$ Geschilbeslechting die wordt georganiseerd door een vereniging die tevens belangenbehartiger is, kan evenwel problematisch zijn indien er, al dan niet terecht, niet voldoende vertrouwen bestaat in de onafhankelijkheid van het oordeel..$^{88} \mathrm{Om}$ transparantie en onafhankelijkheid te kunnen waarborgen, zal geschilbeslechting onder auspiciën van een derde moeten plaatsvinden. ${ }^{89}$ Hierbij kan bijvoorbeeld worden gedacht aan (aansluiting door de NFV en eventuele andere franchiseorganisaties bij) de Stichting Geschillencommissies voor Beroep en Bedrijf. ${ }^{90}$

\section{Conclusie}

In de huidige discussie in de franchisesector over de vraag of nadere regulering van de verhouding tussen franchisegever en franchisenemer gewenst is, ligt de nadruk op het al dan niet codificeren van de franchiseovereenkomst in het BW, waarbij mogelijke alternatieven zoals zelfregulering naar ons oordeel onderbelicht blijven.

85. Uiteraard is een deel van dergelijke kennis nu ook beschikbaar via algemene organisaties die ondernemers bedienen, zoals de Kamers van Koophandel en een website als Ondernemersplein. $\mathrm{nl}$, maar nu de problemen die rijzen specifiek bij franchiseovereenkomsten van dien aard zijn dat zelfs voor codificatie wordt gepleit, kan specifieke voorlichting geen kwaad.

86. Zie <www.nfv.nl>, Geschillen.

87. Hoewel de hoge kosten verbonden aan een arbitrage vaak een onneembare barrière blijken. Ook overigens mogen arbitrage en mediation niet over één kam worden geschoren, zie in dit kader P. van der Veld, Mediation in zakelijke geschillen, V\&O 2012, afl. 9, p. 142-143.

88. Zie bijv. Groot-Brittannië, waar een vorm van geschilbeslechting door de nationale franchisevereniging (BFA) bestaat. Naar keuze kan gebruik worden gemaakt van 'conciliation', 'mediation' en 'arbitration' door de BFA. De ervaringen daarmee zijn wisselend, arbitration lijkt minder succesvol dan conciliation en mediation, onder andere omdat de BFA niet als voldoende onafhankelijk wordt beschouwd. Abell (diss.) 2011, p. 115.

89. Vgl. ook art. 7 van de Italiaanse wet inzake franchising, L nr. 129/2004, waarin staat dat partijen kunnen overeenkomen dat zij, alvorens een geschil voor te leggen aan een gerechtelijke instantie of arbiters, eerst een poging tot bemiddeling zullen doen ten overstaan van de 'Camera di Commercio, Industria, Artigianato e Agricoltura'.

90. De geschillencommissies die hieronder vallen, beslechten geschillen tussen ondernemingen onderling. 
Codificatie van de franchiseovereenkomst is een serieuze optie, nu de franchiseovereenkomst ervoor in aanmerking komt als benoemde overeenkomst te worden opgenomen in Boek 7 BW. ${ }^{91}$ Er zitten evenwel nadelen aan het wettelijk verankeren van de franchiseovereenkomst: zo zal de discussie over het 'normaaltype' van de franchiseovereenkomst gevoerd dienen te worden. Bovendien verdient het aanbeveling om de specifiek op franchise gerichte wetgeving (zie de uiteenzetting in par. 5) in verscheidene Europese landen nader op haar merites te beoordelen, om te bezien of de gewenste bescherming van de franchisenemer in de praktijk ook tot stand komt. ${ }^{92} \mathrm{De}$ op franchise gerichte wetgeving in de andere Europese landen regelt vooral de precontractuele informatieplichten en hoewel dat een belangrijk punt is ten aanzien waarvan behoefte aan regulering bestaat, is het niet het enige knelpunt in de verhouding tussen franchisegever en franchisenemer. De informatieplichten zien veelal op marktomstandigheden en in het verleden behaalde resultaten, maar behelzen geen verplichting om omzet- en winstprognoses te verschaffen.

Dit alles maakt dat, in aanvulling op het onderzoeken van de optie van codificatie van de franchiseovereenkomst, volgens ons versterking van zelfregulering in de franchisesector serieuze aandacht verdient. De branche zou er volgens ons goed aan doen tot overleg te komen om de belangen van zowel de franchisenemers als de franchisegevers te behartigen. De behoefte aan bescherming van franchisenemers (met name in de precontractuele fase van de franchiseovereenkomst) heeft in een aantal andere Europese landen reeds tot wetgeving geleid. De minister lijkt momenteel geen prioriteit te leggen bij wetgeving, ${ }^{93}$ maar het is niet uitgesloten dat hij het voorbeeld van de buitenlandse collega's volgt indien de sector zelf niet in staat blijkt (aspirant-)franchisenemers te beschermen. Dat zou naar onze mening een extra prikkel dienen te zijn voor de sector om te zoeken naar een constructieve oplossing.

Kort voor het afronden van deze bijdrage zijn onder leiding van het ministerie van Economische Zaken de eerste gesprekken van start gegaan om te komen tot betere voorlichting, zelfregulering en strafrechtelijke aanpak van malafide franchiseverhoudingen. De uitkomst hiervan wordt met belangstelling tegemoetgezien.

91. Zie par. 5: zo bestaat er behoefte aan bescherming van een 'zwakke' partij, is de franchiseovereenkomst voldoende te onderscheiden van andere commerciële overeenkomsten, is het een frequent voorkomend type overeenkomst en vertegenwoordigen franchiseovereenkomsten een groot economisch en maatschappelijk belang.

92. In België bijvoorbeeld, waar een vorm van wetgeving inzake precontractuele informatieplichten bestaat, is kritiek op het feit dat er geen specifieke sanctie bestaat indien de franchisegever onjuiste informatie heeft verschaft. Zie par. 5.1.

93. Aanhangsel Handelingen II 2013/14, 788. Zie tevens de kabinetsreactie op meerdere stukken inzake franchiseondernemers d.d. 14 mei 2014. 